DOI: 10.20472/IAC.2017.028.009

\title{
JOY KUTAKA-KENNEDY
}

National University, United States

\section{ONLINE SUPERVISION OF TEACHERS IN THE EXPANDING K-12 ONLINE TEACHING WORLD}

\begin{abstract}
:
In today's word, we are becoming more wired and tech savvy every day. Whole cities, metro systems, universities and school districts have free internet access as we become more technologically embedded in our interconnected world. Many schools offer K-12 students online classes, some districts even requiring that students take an online class before graduating and other districts becoming fully online with no "brick and mortar" classrooms. Despite the growing demand for online teachers, university teacher preparation programs are slow to develop programs to meet the need. Many options exist to broaden the field experience with supervision using online technologies and supports like online synchronous and asynchronous discussion boards, collaborative or self-reflective video analysis and review, and live, real time chats and feedback. Tools such as these can lead the way to program development and expansion to better prepare future teachers for teaching in the K-12 online environment.
\end{abstract}

\section{Keywords:}

online teaching, online supervision, online video tools

JEL Classification: $129,123,120$ 